\title{
Effect of source of starch on net portal flux of glucose, lactate, volatile fatty acids and amino acids in the pig
}

\author{
BY J. VAN DER MEULEN ${ }^{1}$, J. G. M. BAKKER ${ }^{1}$, B. SMITS ${ }^{1}$ AND H. DE VISSER ${ }^{2}$ \\ ${ }^{1}$ Department of Nutrition of Pigs and Poultry, \\ ${ }^{2}$ Department of Ruminant Nutrition, Institute for Animal Science and Health, ID-DLO, PO Box 65, \\ 8200 AB Lelystad, The Netherlands
}

(Received 17 June 1996 - Revised 23 December 1996 - Accepted 3 April 1997)

\begin{abstract}
The ileal digestibilities of maize starch and native pea starch do not differ. However maize starch is digested faster than pea starch and the ileal amino acid digestibility of a diet containing pea starch is lower. In the present study, the net portal fluxes of glucose, lactate, volatile fatty acids (VFA) and amino acids were measured for diets including $650 \mathrm{~g}$ maize starch or pea starch $/ \mathrm{kg}$. The diets were fed at a level $870 \mathrm{~kJ}$ digestible energy $/ \mathrm{kg}^{0.75}$ twice daily (06.00 and 18.00 hours) to four female pigs in a crossover design. Portal vein blood flow did not differ between maize and pea starches (1620 and $1484 \mathrm{ml} / \mathrm{min}$ respectively; SED $100 ; P=0.23$ ). For maize starch portal glucose flux was significantly higher during the first $6 \mathrm{~h}$ after feeding, was not different $8 \mathrm{~h}$ after feeding and was significantly lower thereafter. Net portal glucose flux was higher for maize starch than for pea starch (1759 and $1265 \mathrm{mmol} / 12 \mathrm{~h}$ respectively; SED $182 ; P=\mathbf{0 . 0 5 4})$. Net portal lactate flux was not significantly different between maize and pea starches $(36.5$ and $67.2 \mathrm{mmol} / 12 \mathrm{~h}$ respectively; SED $24.1 ; P=0.27$ ) and net portal VFA flux was lower for maize starch than for pea starch $(169$ and $218 \mathrm{mmol} / 12 \mathrm{~h}$ respectively; SED $18 ; P=0.054)$. Net portal fluxes of valine, isoleucine, phenylalanine, tryptophan, arginine, serine, cystine, tyrosine, lysine, histidine and the sum of essential amino acids tended to be or were higher $(P<0.1$ or $P<0.05)$ and net portal flux of aspartic acid tended to be lower for pea starch $(P<0.1)$. It can be concluded that, although ileal digestibility of both starches is equal, the rate of appearance of glucose in the portal vein was higher for maize starch, influencing the net portal flux of amino acids.
\end{abstract}

Starch: Net portal flux: Amino acids

Enzymic digestion of starch in the small intestine may be incomplete. In vitro studies demonstrate large differences in the degree of degradation of starchy feedstuffs (Heaton $e t$ al. 1988; Cone \& Vlot, 1990). In men 0-30\% of starch is resistant to digestion in the small intestine (Faisant et al. 1993). Also, ileal starch digestibility in pigs does not always equal $100 \%$ and is related to the source and processing of the starch (Wünsche et al. 1987; Graham et al. 1989; van der Poel et al. 1992). Starch which is not digested in the small intestine will enter the large intestine and will be fermented (resistant starch; Cummings \& Englyst, 1995).

Non-resistant starch is digested completely in the small intestine. However the rate of digestion of non-resistant starch in the small intestine may differ depending on the physical form of the food (Leclere et al. 1993; Cummings \& Englyst, 1995). Even the intestinal digestion rates of ground purified non-resistant starches may differ as was shown for maize and native pea starches by Everts $e t$ al. (1996). The rate of disappearance from the small intestine in pigs was faster for maize starch than for native pea starch. Moreover, ileal 
digestibility of $\mathrm{N}$ was positively affected after feeding maize starch (Everts et al. 1996). A decrease in the rate of starch digestion may reduce or delay the postprandial glucose and insulin responses (Cummings \& Englyst, 1995), and a difference in the rate of digestion between carbohydrates and proteins may have nutritional consequences (Rérat, 1985).

In the present study the net portal fluxes of nutrients (glucose, lactate, volatile fatty acids (VFA) and amino acids) after feeding maize starch and native pea starch were measured, in order to obtain a picture of the process and dynamics of carbohydrate digestion of these two non-resistant starches with different digestion rates.

\section{MATERIALS AND METHODS}

\section{Animals}

Four female (Dutch Landrace $\times$ Yorkshire $\times$ Finnish Landrace) pigs (weight 33.3 (SD 1.5 $\mathrm{kg}$ ) were fitted, under general anaesthesia, with catheters in the portal vein and mesenteric vein and artery, according to the procedure described by Huntington et al. (1989) for cattle. After 1 week of recovery from surgery the pigs were housed in metabolism cages and adapted to the experimental diets. The mean weight of the pigs was 39.0 (SD 2.4) $\mathrm{kg}$ at the start of the experiment and 44.0 (SD 3.5) kg at the end of the experiment.

\section{Surgery}

Animal preparation. Before surgery animals were denied food for $24 \mathrm{~h}$ and water for $12 \mathrm{~h}$. Anaesthesia was induced by intramuscular injection of $2 \mathrm{mg}$ azaperone $/ \mathrm{kg}$ (Stresnil; Janssen, Tilburg, The Netherlands) followed within 30 min by intravenous injection of $15 \mathrm{mg}$ Nesdonal/kg (Rhône Mérieux, Lyon, France). The pig was intubated and general anaesthesia was maintained by inhalation anaesthesia with $\mathrm{O}_{2}, \mathrm{~N}_{2} \mathrm{O}$ and halothane. After shaving and disinfecting the surgical sites, the pig was placed in dorsal recumbency. The abdomen was opened by a midline incision of approximately $250 \mathrm{~mm}$. During surgery intestines in the surgical field were rinsed frequently with physiological saline $(9 \mathrm{~g} \mathrm{NaCl} / 1)$ containing $7500 \mathrm{U}$ heparin/l (Leo, Weesp, The Netherlands) and $100000 \mathrm{U}$ procaine penicillin/1 (Combiotic; Pfizer, Rotterdam, The Netherlands).

Catheterization of mesenteric vein and artery. Mesenteric vein and artery were cleared of surrounding tissue by blunt dissection. A catheter (Tygon, i.d. $1.02 \mathrm{~mm}$, o.d. $1.78 \mathrm{~mm}$, length $1 \mathrm{~m}$; Norton, Akron, Ohio, USA) was inserted in the vein and advanced for $100 \mathrm{~mm}$. After patency was confirmed by flushing with physiological saline containing $5 \mathrm{U}$ heparin/ml, the catheter was sutured. An identical catheter was placed in the mesenteric artery. Two mesenteric vein and two mesenteric artery catheters were inserted, to provide optimal mixing of the indicator for blood flow measurement and as insurance in case of loss of patency.

Catheterization of the portal vein. The portal vein was lifted towards the incision. The lymph node lying posterior to the gastroduodenal vein was used to locate the place of insertion. The portal vein was punctured anterior to the gastroduodenal vein with a needle (18 gauge) and a $1 \mathrm{~mm}$ wire guide was inserted into the vein. The needle was removed from the guide and the catheter (Tygon, i.d. $1.27 \mathrm{~mm}$, o.d. $2.29 \mathrm{~mm}$, length $1 \mathrm{~m}$ ) was inserted into the vein by threading over the guide, after which the guide was removed. Location of the tip of the catheter in the vein towards the left lateral lobe of the liver was checked by palpation. Patency of the catheter was checked before the catheter was anchored. 
Exteriorization of the catheters and closure. The pig was placed in left lateral recumbency. The catheters were individually exteriorized dorsally in a line parallel to the spine and secured using a velcro system. The pig was replaced in dorsal recumbency and after a final rinse of $100 \mathrm{ml}$ physiological saline containing $5000 \mathrm{U}$ heparin, $150000 \mathrm{U}$ procaine benzyl penicillin G (Procpen; AUV, Cuijk, The Netherlands) and $2.4 \mathrm{mg}$ dexamethasone (Alfasan, Woerden, The Netherlands), peritoneum, muscle layers and skin were closed. After surgery and between sampling sessions the catheters were filled with physiological saline containing 250 IU heparin, $3000 \mathrm{U}$ procaine benzyl penicillin $\mathrm{G}$ and $0.01 \mathrm{ml}$ benzyl alcohol $/ \mathrm{ml}$. Physiological saline containing $5 \mathrm{U}$ heparin $/ \mathrm{ml}$ was used for flushing catheters during surgery and sampling sessions.

Post-surgery care. Antibiotic (400 mg Ampicillin; AUV) and anodyne (Antipyranal; Alfasan) were given intramuscularly for $3 \mathrm{~d}$ after surgery. The day after surgery the pig was given one-third of its pre-surgery daily feed intake, and was returned to its preoperative intake in $3 \mathrm{~d}$. The catheters were checked weekly for their patency.

\section{Diets}

Diets contained $650 \mathrm{~g}$ maize starch or native pea starch $/ \mathrm{kg}$ and the remaining $350 \mathrm{~g} / \mathrm{kg}$ supplied all amino acids, fat, fibre, minerals and vitamins (Table 1). The diets were mixed with water at a ratio of $1: 4.5(\mathrm{w} / \mathrm{v})$ and fed twice daily $(06.00$ and 18.00 hours) at a feeding level of $870 \mathrm{~kJ}$ digestible energy $/ \mathrm{kg}^{0.75}$

Table 1. Composition and chemical analysis of the diets

\begin{tabular}{|c|c|c|}
\hline & Diet $\mathbf{M}$ & Diet $P$ \\
\hline \multicolumn{3}{|l|}{ Ingredients $(\mathrm{g} / \mathrm{kg})$} \\
\hline Maize starch & $649 \cdot 7$ & - \\
\hline Native pea starch* & - & $669 \cdot 2$ \\
\hline Lucerne (Medicago sativa) meal & 136.8 & 129.1 \\
\hline Potato protein & $149 \cdot 1$ & 140.8 \\
\hline Soyabean oil & $10 \cdot 0$ & 9.4 \\
\hline Cane molasses & $35 \cdot 0$ & 33.1 \\
\hline DL-Methionine & 0.8 & 0.8 \\
\hline L-Tryptophan & 0.3 & 0.3 \\
\hline Mono calcium phosphate & 9.1 & 8.6 \\
\hline Limestone & 4.6 & $4 \cdot 3$ \\
\hline Salt & $2 \cdot 5$ & 2.4 \\
\hline Mineral-vitamin premix $†$ & 1.7 & 1.7 \\
\hline \multicolumn{3}{|l|}{ Component (g/kg DM) } \\
\hline $\mathrm{DM}(\mathrm{g} / \mathrm{kg})$ & 914 & 885 \\
\hline Crude protein & 146 & 146 \\
\hline Ash & 35 & 32 \\
\hline Crude fibre & 45 & 46 \\
\hline Starch & 634 & 639 \\
\hline Sugar & 21 & 18 \\
\hline
\end{tabular}

* Nastar (Cosucra, Momalle, Belgium).

$\uparrow$ Supplied (mg/kg diet): retinol 13, cholecalciferol 3, $\alpha$-tocopherol 16, riboflavin 5, cyanocobalamin 20, nicotinic acid 20, pantothenic acid 17, antioxidant $125, \mathrm{CuSO}_{4} .5 \mathrm{H}_{2} \mathrm{O} 40, \mathrm{FeSO}_{4} .7 \mathrm{H}_{2} \mathrm{O} 430, \mathrm{MnO} 50, \mathrm{ZnSO}_{4} \cdot \mathrm{H}_{2} \mathrm{O} 155, \mathrm{KI} 2$, $\mathrm{Na}_{2} \mathrm{SeO}_{3} .5 \mathrm{H}_{2} \mathrm{O} 0.07$ and choline chloride 300 . 


\section{Experimental design}

Pigs were randomly allocated to one of four treatment combinations in a crossover design comprising the two diets and three periods (Jones \& Kenward, 1989). Each of these three periods comprised an adaptation period of $6 \mathrm{~d}$ while on day 7 blood samples were taken simultaneously from the portal vein and the mesenteric artery at 05.55 hours (just before feeding) and $0.5,1,1.5,2,3,4,6,8,10$ and $12 \mathrm{~h}$ after feeding.

\section{Measuring portal blood flow and nutrient flux}

p-Aminohippuric acid (PAH) infusion. Portal vein blood flow was measured by the continuous infusion indicator-dilution technique employing PAH (Fluka Chemie, Buchs, Switzerland) as indicator (Yen \& Killefer, 1987). PAH $(15 \mathrm{mg} / \mathrm{ml})$ was dissolved in water and $\mathrm{NaOH}$ ( $\mathrm{pH} 7 \cdot 4)$. A priming dose of $\mathrm{PAH}$ was infused into the mesenteric veins. After priming, PAH was infused continuously (16-21 mg/min), starting $1 \mathrm{~h}$ before the first blood sampling and continuing throughout the sampling session.

The required PAH priming dose and infusion rate were determined for each pig several days before the actual experiment started. PAH $(300 \mathrm{mg})$ was administered through a mesenteric vein catheter and arterial plasma PAH concentrations were measured every 5 min over a period of $1 \mathrm{~h}$. By means of the pharmacokinetic computer program PKCALC (Shumaker, 1986) the clearance and distribution volume of PAH were determined, and these were used to calculate the priming dose and infusion rate to attain arterial PAH concentrations of $20 \mathrm{mg} / \mathrm{l}$.

Calculating portal vein blood flow. Portal vein blood flow (PVBF) was calculated by the following equation (Yen \& Killefer, 1987):

$$
\mathrm{PVB}=\mathrm{Ci} \times \mathrm{IR} /\left[\mathrm{PAH}_{\mathrm{p}}\left(100-\mathrm{PCV}_{\mathrm{p}}\right) / 100-\mathrm{PAH}_{\mathrm{a}}\left(100-\mathrm{PCV}_{\mathrm{a}}\right) / 100\right]
$$

where $\mathrm{Ci}$ is the concentration of the PAH infusion solution $(\mathrm{mg} / \mathrm{ml}), \mathrm{IR}$ is the infusion rate of $\mathrm{PAH}(\mathrm{ml} / \mathrm{min}), \mathrm{PAH}_{\mathrm{p}}$ and $\mathrm{PAH}_{\mathrm{a}}$ are $\mathrm{PAH}$ concentrations in portal and arterial blood plasma respectively $(\mathrm{mg} / \mathrm{l})$ and $\mathrm{PCV}_{\mathrm{p}}$ and $\mathrm{PCV}_{\mathrm{a}}$ are packed cell volumes of portal and arterial blood respectively $(\%)$.

Calculating net portal flux of nutrients. Net portal-drained viscera (PDV) flux was calculated by the following equation (Deutz et al. 1992):

$$
\text { PDVflux }=\text { PVPF } \times\left(N_{p}-N_{a}\right)
$$

where PVPF is the portal vein plasma flow and $\mathrm{N}_{\mathrm{p}}$ and $\mathrm{N}_{\mathrm{a}}$ are nutrient concentrations in portal and arterial plasma respectively.

\section{Analysis}

Blood samples were collected in cooled heparinized syringes and placed on ice. After the packed cell volume (PCV) was determined, blood samples were centrifuged $(2500 \mathrm{~g}, 10$ min, $4^{\circ}$ ). Within $24 \mathrm{~h}$ plasma was analysed enzymically for lactate and for glucose (Boehringer Mannheim GmbH, Mannheim, Germany). A portion of the plasma was stored at $-80^{\circ}$ until it was analysed for PAH (Eisemann et al. 1987) and VFA (Reynolds et al. 1986) and a portion was deproteinized and stored until it was analysed for amino acids (de Jonge \& Breuer, 1994). 


\section{Statistics}

The crossover design allowed the possibility of testing carry-over effects, and if necessary correction of these effects. Data were subjected to ANOVA for a crossover design, using the ANOVA procedure of Genstat (Payne et al. 1987) according to the following model: $Y_{i j k}=\mu+A_{i}+P_{j}+T_{k}+e_{i j k}$, where $\mu$ is overall mean, $A_{i}$ is effect of animal, $P_{j}$ is effect of period, $T_{k}$ is effect of treatment, $e_{i j k}$ is residual error with $i=1 \ldots 4, j=1 \ldots 3, k=1 \ldots 2$. The results are given as estimated means corrected for period- and animal-effects from the observations on each treatment.

\section{RESULTS}

\section{Portal vein blood flow rate}

Portal vein blood flow rate was elevated for a period of $6 \mathrm{~h}$ after feeding. Average portal vein blood flow did not differ between maize and pea starches $(1620$ and $1484 \mathrm{ml} / \mathrm{min}$ respectively; SED $100 ; P=0.23$ ).

\section{Glucose}

Portal and arterial glucose concentrations relative to the time of feeding are shown in Fig. 1. The highest portal glucose concentration was observed $0.5 \mathrm{~h}$ after feeding for maize starch and $1 \mathrm{~h}$ after feeding for pea starch. Maize starch showed a second peak in portal glucose concentration $3 \mathrm{~h}$ after feeding. Portal glucose concentration was higher for maize starch up to $8 \mathrm{~h}$ after feeding, but after that it was higher for pea starch. Net portal glucose flux for maize starch was significantly higher during the first $6 \mathrm{~h}$ and significantly lower

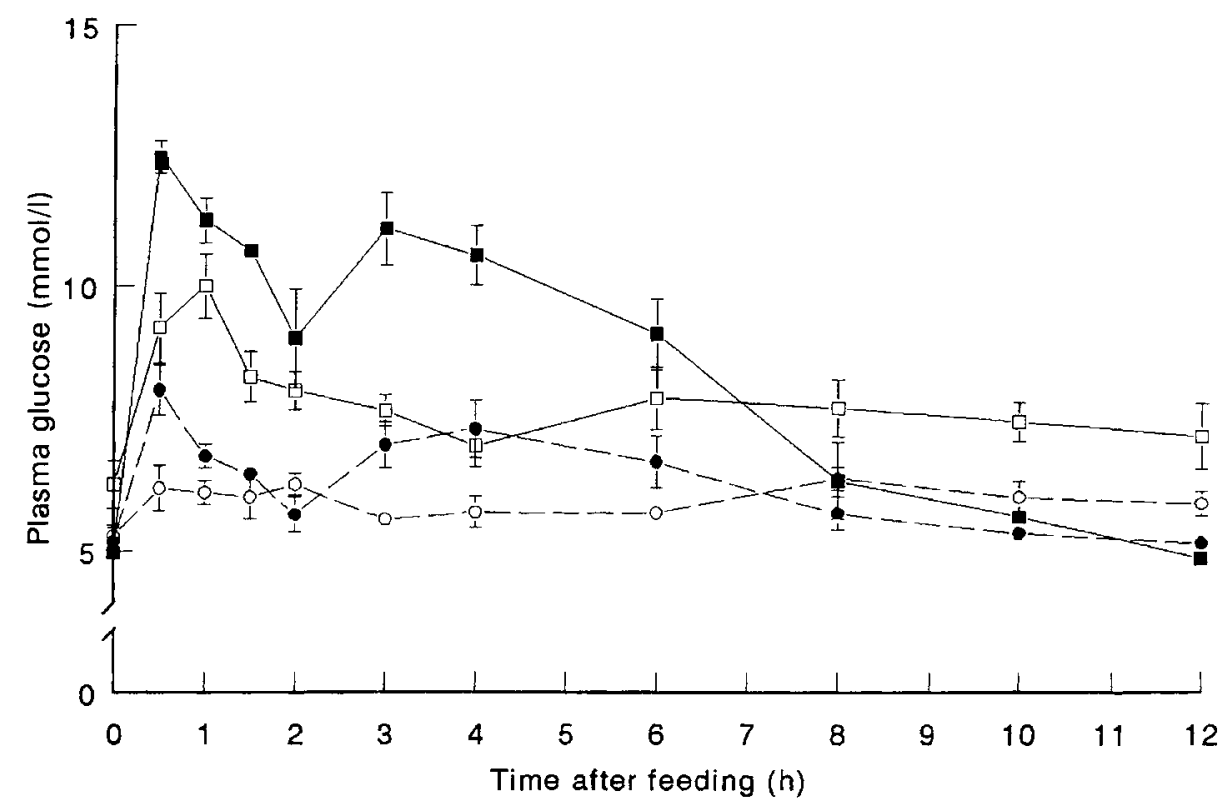

Fig. 1. Portal $(\square, \square)$ and arterial $(O, \ominus)$ plasma glucose concentrations in pigs after consumption of a meal containing maize starch $(\square, O)$ or pea starch $(\square, 0)$. Values are means for four pigs, with their standard errors represented by vertical bars. 


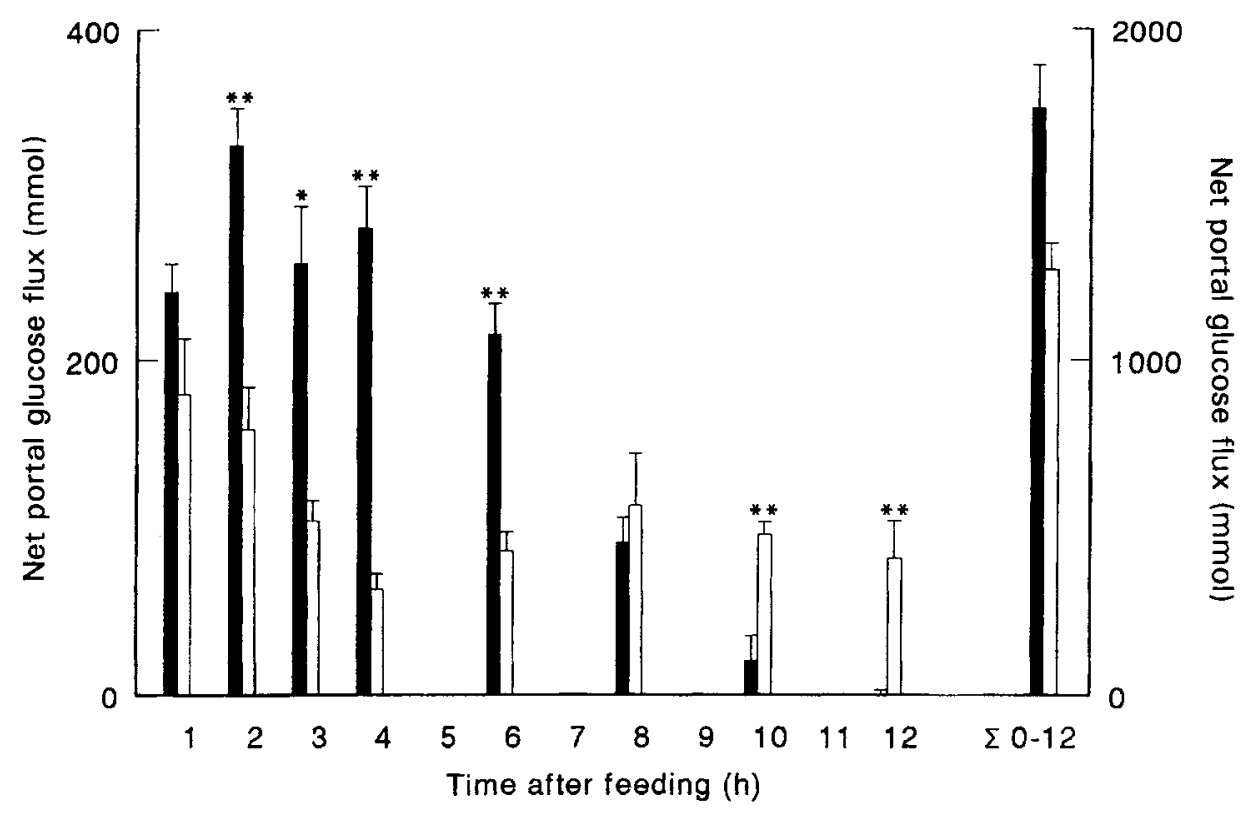

Fig. 2. Net portal flux of glucose in pigs after consumption of a meal containing maize starch ( $\square$ ) or pea starch ( $\square$ ). Values are means for four pigs, with their standard errors represented by vertical bars. Values for the two diets were significantly different: $* P<0.05, * * P<0.01$.

during the last $4 \mathrm{~h}$ after feeding (Fig. 2). The net portal glucose flux over $12 \mathrm{~h}$ was higher for maize starch than for pea starch (1759 and 1265 mmol respectively; SED 182; $P=0.054$; Fig. 2) and accounted for $97 \%$ and $72 \%$ respectively of ileal digested glucose.

\section{Lactate}

Portal lactate concentration relative to the time of feeding (Fig. 3) resembled portal glucose concentration, especially for maize starch (correlations between portal glucose and lactate concentration for maize and pea starches, $r 0.79 ; P<0.01$ and $r 0.45 ; P<0.01$ respectively). Average portal lactate concentrations did not differ between the two diets. However, arterial lactate concentration tended to be higher for maize starch (Fig. 3). Net portal lactate flux relative to the time of feeding (Fig. 4) resembled net portal flux of glucose, except in the hour before and after feeding. Moreover, net portal lactate flux was not significantly different between maize and pea starches $(36.5$ and $67.2 \mathrm{mmol}$ respectively; SED $24 \cdot 1 ; P=0 \cdot 27$; Fig. 4).

\section{Volatile fatty acids}

Neither portal and arterial VFA concentrations, nor the proportions of VFA changed appreciably after feeding. The proportions of VFA were the same for both diets (Table 2). Portal vein contained acetate, propionate, and butyrate in the proportions 76:14:3 and traces of isobutyrate, valerate, isovalerate and caproate. In the artery the proportions were 86:6:1. Portal VFA concentrations was similar for both diets and were always higher than the arterial concentrations. Arterial VFA concentration was higher for maize starch than for 


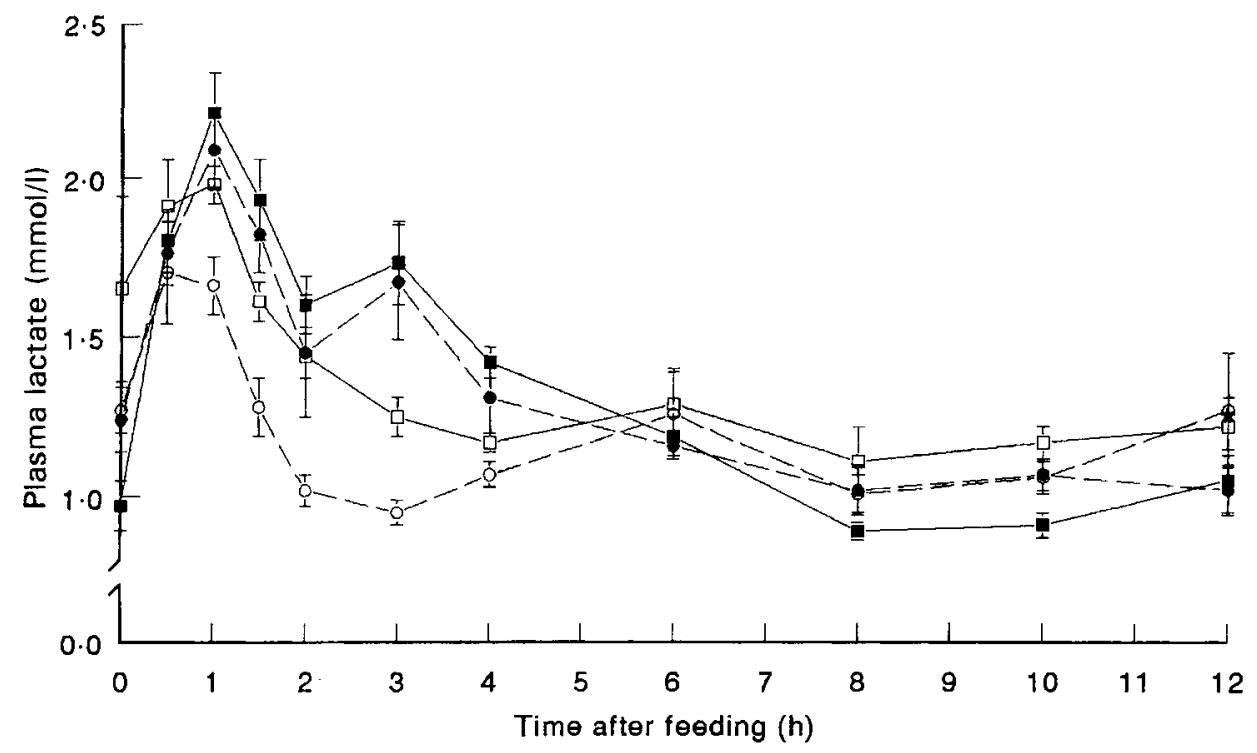

Fig. 3. Portal $(\square, \square)$ and arterial $(O, O)$ plasma lactate concentrations in pigs after consumption of a meal containing

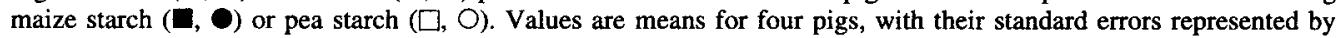
vertical bars.
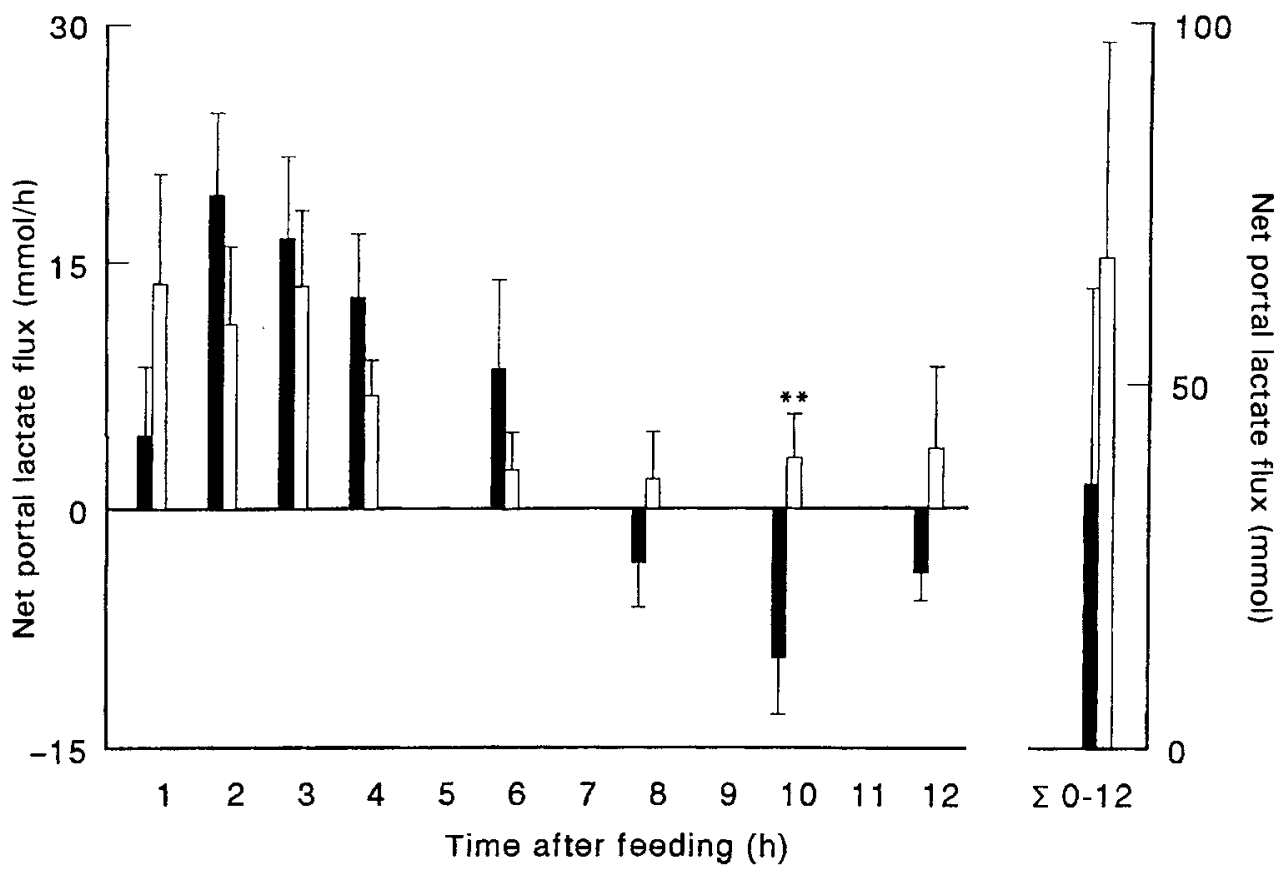

Fig. 4. Net portal flux of lactate in pigs after consumption of a meal containing maize starch $(\square)$ or pea starch $(\square)$. Values are means for four pigs, with their standard errors represented by vertical bars. ** Values for the two diets were significantly different, $P<0.01$. 
Table 2. Mean arterial and portal volatile fatty acid (VFA) concentrations and mean portal flux of VFA in pigs fed on diets containing maize starch or pea starch

\begin{tabular}{|c|c|c|c|c|c|}
\hline & & \multicolumn{2}{|c|}{ Diet } & \multirow[b]{2}{*}{ SED } & \multirow[b]{2}{*}{$\begin{array}{l}\text { Statistical significance } \\
\text { of difference: } P=\end{array}$} \\
\hline & & $\begin{array}{l}\text { Maize } \\
\text { starch }\end{array}$ & $\begin{array}{c}\text { Pea } \\
\text { starch }\end{array}$ & & \\
\hline Artery $(\mathrm{mmol} / \mathrm{l})$ & $\begin{array}{l}\text { VFA } \\
\text { Acetate } \\
\text { Propionate } \\
\text { Butyrate }\end{array}$ & $\begin{array}{l}0.236 \\
0.206 \\
0.012 \\
0.002\end{array}$ & $\begin{array}{l}0.162 \\
0.136 \\
0.010 \\
0.002\end{array}$ & $\begin{array}{l}0.050 \\
0.045 \\
0.002 \\
0.000\end{array}$ & $\begin{array}{l}0.220 \\
0.195 \\
0.476 \\
0.677\end{array}$ \\
\hline Portal vein $(\mathrm{mmol} / \mathrm{l})$ & $\begin{array}{l}\text { VFA } \\
\text { Acetate } \\
\text { Propionate } \\
\text { Butyrate }\end{array}$ & $\begin{array}{l}0.459 \\
0.357 \\
0.058 \\
0.015\end{array}$ & $\begin{array}{l}0.454 \\
0.341 \\
0.070 \\
0.017\end{array}$ & $\begin{array}{l}0.049 \\
0.047 \\
0.006 \\
0.002\end{array}$ & $\begin{array}{l}0.920 \\
0.349 \\
0.131 \\
0.467\end{array}$ \\
\hline Net portal flux (mmol/h) & $\begin{array}{l}\text { VFA } \\
\text { Acetate } \\
\text { Propionate } \\
\text { Butyrate }\end{array}$ & $\begin{array}{r}13.93 \\
9.64 \\
2.75 \\
0.79\end{array}$ & $\begin{array}{r}17.82 \\
12.35 \\
3.72 \\
0.97\end{array}$ & $\begin{array}{l}1.48 \\
1.11 \\
0.45 \\
0.16\end{array}$ & $\begin{array}{l}0.059 \\
0.072 \\
0.323 \\
0.883\end{array}$ \\
\hline
\end{tabular}

pea starch, but this difference was not significant. The hourly net portal VFA flux tended to be higher for pea starch (Table 2). Acetate, propionate and butyrate contributed 69, 20 and $6 \%$ respectively, to the net portal VFA flux. Net portal flux of VFA over $12 \mathrm{~h}$ was $29 \%$ higher for pea starch (maize starch: $169 \mathrm{mmol}$; pea starch: $218 \mathrm{mmol}$; SED $18 ; P=0.054$ ).

\section{Amino acids}

Portal and arterial amino acids concentrations tended to be higher for pea starch than for maize starch. Compared with pea starch, net portal amino acids flux for maize starch was higher between 2 and $4 \mathrm{~h}$ after feeding and otherwise lower, but these differences were not significant, except for $8 \mathrm{~h}$ after feeding. The net portal glutamine and glutamic acid flux was negative (Table 3), showing an uptake by PDV. Also net portal flux of the sum of nonessential amino acids sometimes showed an uptake by PDV particularly for maize starch at about the time of feeding. Net portal flux over $12 \mathrm{~h}$ of pea starch tended to be lower for aspartic acid, but was higher or tended to be higher for valine, isoleucine, phenylalanine, tryptophan, arginine, serine, cystine, tyrosine, lysine, histidine and the sum of essential amino acids $(P<0.1$ or $P<0.05$; Table 3$)$. Portal appearance of ileal digested tyrosine, lysine, serine, valine, cystine, isoleucine, phenylalanine, arginine, histidine, tryptophan and the sum of essential amino acids tended to be or was lower for maize starch than for pea starch (Table 3).

\section{DISCUSSION}

The patterns of appearance of glucose in the portal vein from maize and pea starches were different. Compared with maize starch, the appearance of glucose from pea starch was slower but lasted longer. This agrees with the observation that maize starch is digested faster than pea starch (Everts et al. 1996). The ratio insoluble starch : water-soluble starch in the stomach and cranial part of the small intestine (Everts et al. 1996) indicates a difference in the rate of hydrolysis between maize starch and pea starch. This different 
Table 3. Net portal flux of amino acids in pigs fed on diets containing maize starch or pea starch

\begin{tabular}{|c|c|c|c|c|c|c|c|c|}
\hline \multirow[b]{3}{*}{ Amino acid } & \multicolumn{4}{|c|}{ Net portal flux (mmol) } & \multicolumn{4}{|c|}{ Flux as $\%$ of ileally digested } \\
\hline & \multicolumn{2}{|c|}{ Diet } & \multirow[b]{2}{*}{ SED } & \multirow{2}{*}{$\begin{array}{c}\text { Statistical } \\
\text { significance of } \\
\text { difference: } \\
P=\end{array}$} & \multicolumn{2}{|c|}{ Diet } & \multirow[b]{2}{*}{ SED } & \multirow{2}{*}{$\begin{array}{c}\text { Statistical } \\
\text { significance of } \\
\text { difference: } \\
P=\end{array}$} \\
\hline & $\begin{array}{l}\text { Maize } \\
\text { starch }\end{array}$ & $\begin{array}{c}\text { Pea } \\
\text { starch }\end{array}$ & & & $\begin{array}{l}\text { Maize } \\
\text { starch }\end{array}$ & $\begin{array}{l}\text { Pea } \\
\text { starch }\end{array}$ & & \\
\hline Threonine & $10 \cdot 9$ & $15 \cdot 2$ & $3 \cdot 3$ & 0.274 & 43.8 & 59.3 & 13.9 & 0.330 \\
\hline Valine & $22 \cdot 1$ & 28.6 & 2.9 & 0.087 & $66 \cdot 6$ & $84 \cdot 0$ & 7.9 & 0.091 \\
\hline Cystine & 1.9 & 2.8 & 0.3 & 0.050 & $77 \cdot 2$ & $108 \cdot 1$ & 14.4 & 0.099 \\
\hline Methionine & 8.4 & $9 \cdot 6$ & 0.8 & 0.217 & $93 \cdot 3$ & $99 \cdot 2$ & $7 \cdot 4$ & 0.470 \\
\hline Isoleucine & 19.8 & $24 \cdot 0$ & 1.6 & 0.066 & $83 \cdot 3$ & 97.7 & 5.7 & 0.066 \\
\hline Leucine & $35 \cdot 0$ & $40 \cdot 9$ & $2 \cdot 9$ & 0.115 & $86 \cdot 4$ & 99.0 & $6 \cdot 0$ & $0 \cdot 105$ \\
\hline Tyrosine & $13 \cdot 5$ & $16 \cdot 7$ & 0.6 & 0.008 & $85 \cdot 6$ & $100 \cdot 2$ & 2.7 & 0.006 \\
\hline Phenylalanine & 19.5 & $22 \cdot 8$ & $1 \cdot 3$ & 0.068 & 94.5 & $106 \cdot 8$ & $5 \cdot 0$ & 0.071 \\
\hline Lysine & $24 \cdot 1$ & $31 \cdot 0$ & 1.7 & 0.017 & $82 \cdot 5$ & $109 \cdot 3$ & $5 \cdot 3$ & 0.007 \\
\hline Histidine & $7 \cdot 2$ & $8 \cdot 6$ & 0.5 & 0.054 & 107.5 & $127 \cdot 4$ & $7 \cdot 3$ & 0.052 \\
\hline Tryptophan & 2.6 & $3 \cdot 7$ & 0.4 & 0.082 & $74 \cdot 1$ & 110.6 & $13 \cdot 3$ & 0.052 \\
\hline Arginine & $17 \cdot 1$ & $20 \cdot 1$ & $1 \cdot 1$ & 0.066 & $109 \cdot 2$ & 123.9 & $6 \cdot 5$ & 0.086 \\
\hline EAA & $182 \cdot 6$ & 224.4 & $12 \cdot 7$ & 0.030 & 79.9 & $96 \cdot 0$ & $4 \cdot 2$ & 0.019 \\
\hline Aspartic acid & $3 \cdot 7$ & $2 \cdot 6$ & 0.4 & 0.071 & $49 \cdot 1 *$ & $47 \cdot 2^{*}$ & $2 \cdot 3$ & 0.478 \\
\hline Asparagine & $22 \cdot 3$ & $23 \cdot 3$ & $1 \cdot 1$ & 0.452 & & & & \\
\hline Glutamic acid & -7.4 & -8.8 & $2 \cdot 7$ & 0.653 & $-187.0 \dagger$ & $-178 \cdot 3 \dagger$ & $23 \cdot 0$ & 0.725 \\
\hline Glutamine & $-66 \cdot 2$ & -62.9 & $7 \cdot 3$ & 0.677 & & & & \\
\hline Serine & $25 \cdot 8$ & $28 \cdot 8$ & $1 \cdot 3$ & 0.084 & $94 \cdot 2$ & $102 \cdot 4$ & 3.8 & 0.105 \\
\hline Glycine & 23.1 & $25 \cdot 5$ & $7 \cdot 0$ & 0.745 & $68 \cdot 1$ & 73.9 & $22 \cdot 3$ & 0.807 \\
\hline Alanine & 57.2 & $65 \cdot 4$ & 4.7 & 0.160 & $193 \cdot 3$ & $215 \cdot 8$ & 14.8 & 0.205 \\
\hline Proline & $12 \cdot 7$ & 14.6 & $2 \cdot 6$ & 0.512 & $48 \cdot 1$ & $56 \cdot 6$ & $17 \cdot 0$ & 0.643 \\
\hline NEAA & $71 \cdot 3$ & 88.7 & $22 \cdot 1$ & 0.477 & $34 \cdot 2$ & $41 \cdot 8$ & $10 \cdot 8$ & 0.523 \\
\hline Taurine & -1.0 & -0.8 & 1.0 & 0.832 & & & & \\
\hline Citrulline & $10 \cdot 3$ & $11 \cdot 0$ & 0.5 & 0.277 & & & & \\
\hline Omithine & $2 \cdot 8$ & $3 \cdot 6$ & 0.5 & 0.208 & & & & \\
\hline TAA & 253.9 & $313 \cdot 1$ & $30 \cdot 5$ & 0.124 & $60 \cdot 6$ & $73 \cdot 0$ & $7 \cdot 2$ & 0.161 \\
\hline
\end{tabular}

EAA, essential amino acids; NEAA, non-essential amino acids; TAA, total amino acids.

* Combined flux of asparagine plus aspartic acid.

$\dagger$ Combined flux of glutamine plus glutamic acid.

hydrolysis rate may be responsible for the different pattern of appearance of glucose. Borgida \& Laplace (1977) found that gastric emptying was $40 \%$ more rapid when hydrolysis of potato starch was made easier by extrusion. Also differences in ileal digestibility between non-resistant starch and resistant starch are attributed to differences in hydrolysis (Cummings \& Englyst, 1995) and Rérat et al. (1984) suggested that the ratelimiting factor for appearance of glucose from maize starch in the portal vein is the rate of enzymic hydrolysis. The appearance of two peaks of glucose in the portal vein for maize starch has also been measured for a diet containing rapeseed concentrate but not for a diet containing casein (Galibois et al. 1989). Therefore the appearance of one or two peaks of glucose in the portal vein after feeding maize starch seems to depend, also, on diet components other than starch (Galibois et al. 1989).

The total amount of glucose absorbed over $12 \mathrm{~h}$ was lower for pea starch than for maize starch. However, ileal digestibility of pea starch is nearly $100 \%$ (Berggren et al. 
1995; Everts et al. 1996), and is not different from ileal digestibility of maize starch (Everts et al. 1996). This implies that after feeding pea starch more glucose may be used as an oxidative substrate by the small-intestinal wall, or that part of the pea starch is fermented in the stomach or small intestine. Although microbial activity is low in the stomach and in the cranial two-thirds of the small intestine, it increases in the distal third of the small intestine (Jensen, 1988; Bach Knudsen et al. 1991) and a significant pre-caecal fermentation of NSP may occur (Bach Knudsen et al. 1991). Lactate and VFA are the end-products of fermentation in the stomach and small intestine, while in the large intestine VFA are the principal products (Argenzio \& Southworth, 1974). The net portal flux of lactate was higher after feeding pea starch, but the difference with maize starch was not significant. However, lactate is not only an end-product of fermentation in the stomach and small intestine. Lactate may also be derived from metabolism of glutamine (Rérat \& Corring, 1991) and glucose (Giusi-Perier et al. 1989) in the gut wall. The latter is supported by the correlation between the portal glucose and lactate concentration, although this correlation was not as high as that found by Giusi-Perier et al. (1989). The net portal VFA flux showed a higher fermentation for pea starch than for maize starch. However, increased fermentation in the large intestine, probably promoted by the higher $\mathrm{N}$ flow into the large intestine (Everts et al. 1996), may also have contributed to the higher net portal VFA flux. Acetate was the main component of this higher net portal VFA flux, as has been observed for fermentation of resistant starch in rats (Morand et al. 1991). Recently it has been suggested that VFA provoke the release of enteroglucan, which inhibits, among other things, gastric emptying (Gee et al. 1996). By inhibiting gastric emptying the higher fermentation for pea starch may contribute to the slower appearance of glucose from pea starch.

Net portal flux of glutamine was negative indicating an uptake of glutamine by the gastrointestinal wall. Glutamine is a major oxidative substrate for the small intestine (Rérat \& Corring, 1991). Net portal flux of some amino acids was higher for pea starch than for maize starch, while the ileal amino acid digestibility is lower (Everts et al. 1996). The lower ileal amino acid digestibility for pea starch may have been caused by the reduced passage rate and the slower rate of starch digestion, resulting in a higher endogenous secretion (Everts et al. 1996). On the other hand, the slower rate of digestion of pea starch provided a more gradual supply of nutrients to the intestinal tissues, as can be seen from the net portal flux of glucose which approached zero $10 \mathrm{~h}$ after feeding maize starch but continued until the next feed for pea starch. A more gradual supply of glucose to the intestinal tissues also occurs for a diet containing maize starch compared with the same diet in which $35 \%$ of maize starch is replaced by lactose, resulting in a $20 \%$ higher net portal flux of amino- $\mathrm{N}$ for the diet with the more gradual supply of glucose (Giusi-Perier et al. 1989). The appearance of amino-N also differs when oligopeptides are infused into the duodenum in the presence of maltitol or maltose (Rérat et al. 1991).

A higher passage rate may reduce the contact time between feeds and enzymes and may result in incomplete hydrolysis of proteins (Giusi-Perier et al. 1989). On the other hand, a lower passage rate resulting in a more gradual supply of nutrients to the intestinal tissues, may have affected the mutual inhibition of sugars and amino acids during intestinal absorption (Vinardell, 1990; Rérat et al. 1991).

From the present study it may be concluded that, even though the ileal digestibilities of starches do not differ and approach $100 \%$, the rate of appearance of glucose in the portal vein and the net portal flux of glucose may be different. Moreover, the net portal flux of amino acids may be affected by the type of non-resistant starch in the diet. 
The authors gratefully acknowledge the financial support of the Commodity Board for Feedstuffs (The Netherlands) and the technical assistance of the staff of the metabolism unit and the laboratory.

\section{REFERENCES}

Argenzio, R. A. \& Southworth, M. (1974). Sites of organic acid production and absorption in the gastrointestinal tract of the pig. Journal of Physiology 228, 454-460.

Bach Knudsen, K. E., Jensen, B. B., Andersen, J. O. \& Hansen, I. (1991). Gastrointestinal implications in pigs of wheat and oat fractions. 2. Microbial activity in the gastrointestinal tract. British Journal of Nutrition 65, 233248.

Berggren, A. M., Björck, I. M. E., Margareta, E. \& Nyman, G. L. (1995). Short-chain fatty acid content and pH in caecum of rats fed various sources of starch. Journal of the Science of Food and Agriculture 68, 241-248.

Borgida, L. P. \& Laplace, J. P. (1977). Evacuation gastrique comparée de régimes à base de fécule de pomme de terre crué ou extrudée chez le porc en croissance (A comparative study of the gastric emptying of diets containing either raw or extruded potato starch in growing pigs). Annals de Zootechnie 26, 585-593.

Cone, J. W. \& Vlot, M. (1990). Comparison of degradability of starch in concentrates by enzymes and rumen fluid. Journal of Animal Physiology and Animal Nutrition 63, 142-148.

Cummings, J. H. \& Englyst, H. N. (1995). Gastrointestinal effects of food carbohydrate. American Journal of Clinical Nutrition 61, 938S-945S.

de Jonge, L. H. \& Breuer, M. (1994). Modification of the analysis of amino acids in pig plasma. Journal of Chromatography $B$ 652, 90-96.

Deutz, N. E. P., Reijven, P. L. M., Athanasas, G. \& Soeters, P. (1992). Post-operative changes in hepatic, intestinal, splenic and muscle fluxes of amino acids and ammonia in pigs. Clinical Science 83, 607-614.

Eisemann, J. H., Huntington, G. B. \& Ferrell, C. L. (1987). Blood flow to hindquarters of steers measured by transit ultrasound and indicator dilution. Journal of Dairy Science 70, 1385-1390.

Everts, H., Dekker, R. A., Smits, B. \& Cone, J. W. (1996). The digestion of maize and native pea starch in the small intestine of pigs. Proceedings of the Nutrition Society 55, 59A.

Faisant, N., Champ, M., Colonna, P. \& Buleon, A. (1993). Structural features of starch that escapes digestion in the small intestine of humans. In Proceedings of 'Bioavailability 93' part 1, pp. 146-150 [U. Schlemmer, editor]. Karlsruhe: BFE.

Galibois, I., Simoes Nuñes, C., Rérat, A. \& Savoie, I. (1989). Net appearance of amino acids in portal blood during the digestion of casein or rapeseed proteins in the pig. Canadian Journal of Physiology and Pharmacology 67, 1409-1417.

Gee, J. M., Lee-Finglas, W. \& Johnson, I. T. (1996). Fermentable carbohydrate modulates postprandial enteroglucagon and gastrin release in rats. British Journal of Nutrition 75, 757-766.

Giusi-Perier, A., Fiszlewicz, M. \& Rérat, A. (1989). Influence of diet composition on intestinal volatile fatty acid and nutrient absorption in unanesthetized pigs. Journal of Animal Science 67, 386-402.

Graham, H., Löwgren, W. \& Åman, P. (1989). An in vitro method for studying digestion in the pig. 2. Comparison with in vivo ileal and faecal digestibilities. British Journal of Nutrition 61, 689-698.

Heaton, K. W., Marcus, S. N., Emmett, P. M. \& Bolton, C. H. (1988). Particle size of wheat, maize and oat meals: effects on plasma glucose and insulin responses and on the rate of starch digestion in vitro. American Journal of Clinical Nutrition 47, 675-682.

Huntington, G. B., Reynolds, C. K. \& Stroud, B. H. (1989). Techniques for measuring blood flow in splanchnic tissue of cattle. Journal of Dairy Science 72, 1583-1595.

Jensen, B. B. (1988). Effect of diet composition and virginiamycin on microbial activity in the digestive tract of pigs. In Digestive Physiology in the Pig, pp. 392-400 [L. Buraczewska, S. Buraczewski, B. Pastuszewska and T. Zebrowska, editors]. Jablonna: Polish Academy of Sciences.

Jones, B. \& Kenward, M. G. (1989). Design and Analysis of Cross-over Trials. London: Chapman and Hall.

Leclere, C., Lairon, D., Champ, M. \& Cherbut, C. (1993). Influence of particle size and sources of non-starch polysaccharides on postprandial glycaemia, insulinaemia and triacylglycerolaemia in pigs and starch digestion in vitro. British Journal of Nutrition 70, 179-188.

Morand, C., Rémésy, C., Levrat, M.-A. \& Demigné, C. (1991). Replacement of digestible wheat starch by resistant cornstarch alters splanchnic metabolism in rats. Journal of Nutrition 122, 345-354.

Payne, R. W., Lane, P. W., Ainsley, A. E., Dicknell, K. E., Digby, P. G. N., Harding, S. A., Leech, P. K., Simpson, H. R., Todd, A. D., Verrier, P. J., White, P. W., Gower, J. C., Tunnicliffe Wilson, G. \& Paterson, L. J. (1987). Genstat 5 Reference Manual. New York: Oxford University Press.

Rérat, A. (1985). Intestinal absorption of end products from digestion of carbohydrates and proteins in the pig. Archives of Animal Nutrition 35, 461-480.

Rérat, A. \& Corring, T. (1991). Animal factors affecting protein digestion and absorption. In Digestive Physiology in Pigs, pp. 5-34 [M. W. A. Verstegen, J. Huisman and L. A. den Hartog, editors]. Wageningen: Pudoc. 
Rérat, A., Vaissade, P. \& Vaugelade, P. (1984). Absorption kinetics of some carbohydrates in conscious pigs. 2. Quantitative aspects. British Journal of Nutrition 51, 517-529.

Rérat, A., Vaissade, P. \& Vaugelade, P. (1991). Comparative digestion of maltitol and maltose in unanesthetized pigs. Journal of Nutrition 121, 737-744.

Reynolds, P. J., Huntington, G. B. \& Reynolds, C. K. (1986). Determination of volatile fatty acids, lactate and $\beta$ hydroxybutyrate in blood by ion exchange cleanup and gas chromatography. Journal of Animal Science 63, Suppl. 1, 424.

Shumaker, R. C. (1986). PKCALC: a basic interactive computer program for statistical and pharmacokinetic analysis of data. Drug Metabolism Reviews 17, 331-348.

van der Poel, A. F. B., Gravendeel, S., van Kleef, D. J., Jansman, A. J. M. \& Kemp, B. (1992). Tannin containing faba beans (Vicia faba L.): effects of methods of processing on ileal digestibility of protein and starch for growing pigs. Animal Feed Science and Technology 36, 205-214.

Vinardell, M. P. (1990). Mutual inhibition of sugars and amino acid intestinal absorption. Comparative Biochemistry and Physiology 95, 17-21.

Wünsche, J., Meinl, M., Hennig, U., Borgmann, E., Kreienberg, F. \& Bock, H. H. (1987). Einflu $\beta$ einer thermische Behandlung von Kartoffelprodukten auf den Nährstoffabbau im Verdauungstrakt des Schweines. 1. Passage und Verdaulichkeit der Nährstoffe in den verschiedenen Darmabschnitten (Influence of a thermic treatment of potato products on nutrient degradation in the digestive tract of pigs. 1. Passage and digestibility of the nutrients in various sections of the digestive tract). Archives of Animal Nutrition 37, 461 -480 .

Yen, J. T. \& Killefer, J. (1987). A method for chronically quantifying net absorption of nutrients and gut metabolites into hepatic portal vein in conscious swine. Journal of Animal Science 64, 923-934. 